\title{
NOTES ON THE OSTEOLOGY OF THE SPOTTED TINAMOU (NOTHURA MACULOSA).
}

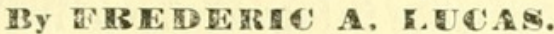

Dr. Parker's well-known memoir on the Osteology of the Tinamous treats the group so thoroughly that little or nothing remains to be done in that direction, except to notice any points wherein species not hitherto described differ from those that have been.

A skeleton of the Spotted Tinamon (Nothura maculosa) recently acquired by the National Musemm presents some interestiug features which scem worthy of description.

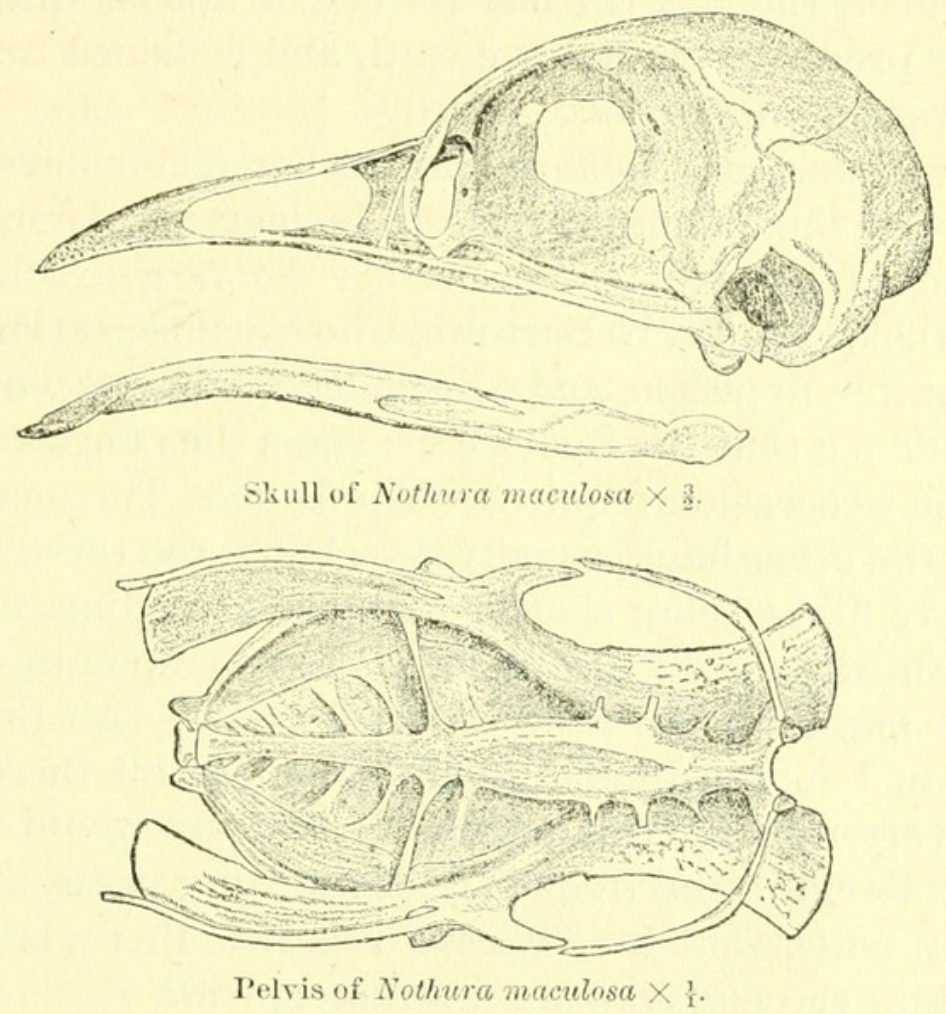

As is well known, one of the most curious, as well as most noticeable characters of the Tinamine skill is the presence of a chain of supraorbital ossicles firmily attached to the stull and completely roofing over the eje.

This feature is entirely lacking in the Spotted Tinamou, the interorbital portion of the cranium being much contracted.

The beak of Nothura is comparatively short and curved, being in marked contrast to that of Tinamus robusius, while the general resemblance of the skull to that of a fowl is quite noticeable.

There being no skeleton in the Museum of any species of Tinamou save the one under consideration, comparisons of all parts but the skull rest upon descriptions and figeres alone.

The first three dorsals of Nothura are fused in one mass, this being an exception to what is ordinarily found, not only in the Tinamous but in the fowls. The usual rule is that the last cervical anchyloses with the succeeding three dorsals, this fusion of vertebre compensat- 
ing for the loss of strength occasioned by the great lateral compression of these bones.

Four ribs are connected with the sternum, one more than in Tinamus robustus or Crypturus megapodius. A fifth sternal rib is present, although separated by a wide interval from its corresponding dorsal rib. The sixth and last rib is very peculiar, for instead of pointing downward it is turned so abruptly backward that the terminal portion very nearly touches the great preacetabular process of the pubis, the two being intimately connected by ligament.

Judging from the published figures, this condition does not exist in either Tinamus robustus or Crypturus megapodius, although curiously enough it is a modification of what is found in Apteryx australis. In Apteryx, however, the last rib has its origin almost directly over the preacetabular process, points downward, and is joined to the pubis by ligament at its median portion.

Like other Tinamous, Nothura has rather feebly-developed wings. Still the crest of the humerus seems to be more prominent than in its relations, and so far as I can ascertain Nothura excels them all in flight. My friend, Mr. W. B. Barrows, who spent some time in Uruguay and the Argentine Republic, and who collected the specimen under consideration, tells me that the Spotted Tinamou flies for considerable distances as often as occasion requires. The Rufons Tinamou (Rhynchotus rufescens), on the other hand, usually rises but three times in succession, each successive flight being shorter than the preceding, until after settling for the third time the bird is forced to rely upon its legs alone.

The radius and ulna are widely bowed apart. As this occurs also in the fowls and in the humming-birds, and as all these birds move their wings very rapidly, this peculiar curvature would seem to have some direct relation to the frequency of the wing beats.

Dr. Parker notes that in Tinamus robustus there is no calcaneal ossicle, and that the nails have a reptilian sprawl.

In Nothura, on the contrary, a large calcaneal sesamoid is present, and so far as may be determined by the terminal phalanges the nails themselves diverge no more than in Gallina.

In all the particulars above mentioned (save the modification of the last rib) the Spotted Tinamou more nearly approaches the fowls than do other described species, and would therefore seem to deserve a leading place in the order to which it belongs.

It may not be out of place in this paper to add a word or two concerning the habits of the Tinamous. It has been quite positively stated that these birds are strictly terrestrial in their mode of life and never alight in trees. Now it is a fact that some species reside in regions subject to sudden floods, where, like the historic beaver, it would seem that they must take to a tree, and Waterton states that a species found in Guiana habitually sleeps in trees, the peculiar scutellation of the tarsi enabling the bird to roost in safety, although the structure of the feet does not permit a firm grasp of the boughs. 


\section{$2 \mathrm{BHL}$ Biodiversity Heritage Library}

Lucas, Frederic A. 1887. "Notes on the osteology of the spotted tinamou (Nothura maculosa)." Proceedings of the United States National Museum 10(622), 157-158. https://doi.org/10.5479/si.00963801.10-622.157.

View This Item Online: https://www.biodiversitylibrary.org/item/32314

DOI: https://doi.org/10.5479/si.00963801.10-622.157

Permalink: https://www.biodiversitylibrary.org/partpdf/23719

\section{Holding Institution}

Smithsonian Libraries

\section{Sponsored by}

Smithsonian

\section{Copyright \& Reuse}

Copyright Status: NOT_IN_COPYRIGHT

This document was created from content at the Biodiversity Heritage Library, the world's largest open access digital library for biodiversity literature and archives. Visit BHL at https://www.biodiversitylibrary.org. 